\title{
DNA extraction from human saliva deposited on skin and its use in forensic identification procedures
}

\section{Extração de DNA de saliva humana depositada sobre a pele e sua aplicabilidade aos processos de identificação forense}

\author{
Evelyn Anzai-Kanto* \\ Mário Hiroyuki Hirata** \\ Rosario Dominguez Crespo Hirata** \\ Fabio Daumas Nunes*** \\ Rodolfo Francisco Haltenhoff Melani**** \\ Rogério Nogueira Oliveira****
}

\begin{abstract}
Saliva is usually deposited in bite marks found in many homicides, assault and other criminal cases. In the present study, saliva obtained from volunteers was deposited on skin and recovered for DNA extraction and typing in order to evaluate its usefulness for practical case investigation and discuss the contribution of forensic dentistry to saliva DNA typing. Twenty saliva samples were colleted from different donors and used as suspects' samples. Five of these samples were randomly selected and deposited $(250 \mu 1)$ on arm skin. Saliva was collected from skin using the double swab technique. DNA from saliva and skin-deposited saliva samples was extracted by the phenol-chloroform method. DNA samples were amplified by PCR for DNA typing using a set of 15 STRs. The recovery of DNA from saliva deposited in the skin was 14 to 10 times lower than DNA quantity from saliva samples. DNA typing was demonstrated in 4 of 5 deposited saliva samples, the likelihood ratios estimated for these samples based on data of the Brazilian population were $1: 11,1: 500,1: 159.140$ and 1:153.700.123. Our results indicate that standardized procedures used for DNA collection and extraction from skin-deposited saliva can be used as a method to recover salivary DNA in criminal cases. However, it is important to observe that DNA recovery in forensic samples can be difficult. This study suggests that the analysis of saliva deposited on skin be incorporated into a criminal investigation since it may have great discriminatory power.
\end{abstract}

DESCRIPTORS: DNA; Forensic dentistry; Saliva.

\begin{abstract}
RESUMO: A saliva é usualmente depositada em marcas de mordida encontradas em homicídios, agressões e outros crimes. Neste estudo, a saliva obtida de voluntários foi depositada na pele, recuperada para extração e tipagem do DNA, para avaliação de sua utilização e sua contribuição na odontologia legal. Vinte amostras de saliva foram coletadas de diferentes doadores e utilizadas como amostras de suspeitos. Cinco dessas amostras foram sorteadas e depositadas $(250 \mu 1)$ na pele. A saliva foi coletada da pele usando-se a técnica do duplo esfregaço. O DNA da saliva e das amostras de saliva depositadas sobre a pele foi extraído pelo método fenol-clorofórmio. As amostras de DNA foram amplificadas por PCR para a tipagem do DNA usando-se um grupo de 15 STRs. O DNA recuperado da saliva depositada na pele foi de 14 a 10 vezes menor que o DNA das 20 amostras de saliva. O perfil do DNA foi demonstrado em 4 de 5 amostras de saliva depositadas, e a razão de verossimilhança das amostras baseada em dados da população brasileira foi $1: 11,1: 500,1: 159,140$ e 1:153,700,123. Nossos resultados indicam que procedimentos padronizados utilizados para coleta e extração de DNA de saliva depositada podem ser utilizados como um método para recuperar DNA de saliva em casos forenses; entretanto, é importante observar que amostras forenses podem apresentar problemas na recuperação do DNA em quantidades adequadas. Este estudo sugere que a análise de saliva depositada sobre a pele pode ser incorporada ao conjunto de provas de um inquérito criminal já que possui um grande poder discriminatório.
\end{abstract}

DESCRITORES: DNA; Odontologia legal; Saliva.

\section{INTRODUCTION}

The dental forensic field includes the identification of unknown human remains as part of a crime or disaster investigation. It also includes the analysis of stains and organic liquids from the buc-

\footnotetext{
*MSc; **Associate Professors, Department of Clinical and Toxicological Analysis, School of Pharmaceutical Sciences; ***Full Professor, Department of Stomatology, School of Dentistry; ****Assistant Professors, Department of Social Dentistry, School of Dentistry - University of São Paulo.
} 
Anzai-Kanto E, Hirata MH, Hirata RDC, Nunes FD, Melani RFH, Oliveira RN. DNA extraction from human saliva deposited on skin and its use in forensic identification procedures. Braz Oral Res 2005;19(3):216-22.

cal cavity or its contents, bite mark comparison, investigation of trauma and oral injuries such as personal injury cases, and dental malpractice ${ }^{5}$. In criminal investigations, one of the fundamental requirements is that the victim and aggressor be positively identified.

Forensic dentistry contributes to the forensic process by either a direct comparison of the deceased's dentition with that of known dental records or by enabling a profile of the individual regarding age at death, sex and possible racial ancestry in order to narrow down the search for a possible victim ${ }^{5,8}$.

Saliva may be found on victims of several violent crimes ${ }^{29}$. It has been shown that saliva can potentially be recovered and typed from bite marks ${ }^{3-5,25}$, cigarette butts, postage stamps, envelopes and other objects ${ }^{9,22,24}$. Stains of dried saliva are invisible, making its recognition and collection difficult ${ }^{24}$. However, the presence of saliva can be confirmed by an amylase assay 9 .

In a bite mark, tooth in combination with other mouthparts cause a mark on victims' skin or some object, which can be compared with the unique characteristics of a suspected biter's dentition by several methodologies ${ }^{3,5,29}$. There is no agreement among forensic dentists about the individuality (uniqueness) of the dentition or the behavior of human skin during biting. Nevertheless, distortions may modify, complicate or render impossible the interpretation of a bite mark. Different distortions can occur at different stages in the action of biting, such as dynamic and tissue distortions, and during examination and evidence recording ${ }^{25}$.

Besides the physical evidence present in a bite mark, there is biological evidence that can assist the investigation. During the biting process, saliva is deposited on the skin or object surface in enough amount to allow typing of the deoxyribonucleic acid (DNA) ${ }^{23,25}$. For this purpose, the bite mark area is swabbed using the standard bite mark operating procedures, and DNA can be extracted and analyzed $^{22,25}$.

Polymerase chain reaction (PCR) allows replication of thousands of copies of a specific DNA sequence in vitro, enabling the study of small amounts of $\mathrm{DNA}^{20}$. The polymorphic repair of short tandem repeats (STR) mainly in small fragments also makes it possible to evaluate DNA from samples with a significant grade of degradation. A very important step from this procedure is to obtain DNA from this small amount $t^{9,14,22,26}$.

In the present study, saliva obtained from volunteers was deposited in the skin and recovered for DNA extraction and typing in order to evaluate its usefulness for practical case investigation and discuss the contribution of forensic dentistry to saliva DNA typing.

\section{MATERIALS AND METHODS Samples}

Saliva samples were collected from 20 nonrelated volunteers (11 male and 9 female, 24 to 47 years old) by asking them to spit into sterile plastic test containers (STLU Ind. e Com. de Artefatos Plásticos Ltda. - Me, São Paulo, SP, Brazil). Then, $1.5 \mathrm{ml}$ of saliva sample from each donor were transferred to two $1.5 \mathrm{ml}$ cryotubes (Axygen Scientific, Union City, CA, USA) and frozen at $-20^{\circ} \mathrm{C}$. The samples were collected at least 30 minutes after eating, drinking, smoking or kissing to minimize DNA contamination or PCR inhibitors ${ }^{21}$.

Five samples from the 20 donors were randomly chosen to deposit part of saliva on skin. For this purpose, saliva samples were deposited individually on one of the researchers' arm. Saliva was collected from this researcher to establish his DNA typing to be compared with the saliva donors' profiles.

The samples were obtained after informed consent from Brazilian donors, after the study protocol was approved by the Research Ethics Committee of the School of Dentistry, University of São Paulo (process number 41/01).

\section{Experimental saliva deposition on the skin}

Two hundred and fifty microliters from each saliva sample were placed on five delimited areas of the researcher's arm and skin areas were delimited with a marker pen. Harvey ${ }^{8}$ (1976) estimated that $0.3 \mathrm{ml}$ of saliva is deposited when making a bite mark; in this study, we used $0.25 \mathrm{ml}$ to simulate the minor recuperation of saliva stain. After 10 minutes, the dried saliva was colleted from the skin by the double swab technique using a wet cotton swab (Vacutest Kima s.r.1., Arzergrande, PD, Italy) followed by a dry cotton $\mathrm{swab}^{23}$, and DNA was immediately extracted.

\section{DNA extraction and quantification}

Saliva samples $(1.5 \mathrm{ml})$ were centrifuged (CELM LS-3, São Paulo, SP, Brazil) at 3,000 rpm for 10 minutes at room temperature to separate only cell pellets. The skin swabs were broken and only their cotton parts were disposed in a $1.5 \mathrm{ml}$ propylene tube (Axygen Scientific, Union City, CA, USA); they were hydrated with sterile water before DNA extraction. After this initial preparation, 
Anzai-Kanto E, Hirata MH, Hirata RDC, Nunes FD, Melani RFH, Oliveira RN. DNA extraction from human saliva deposited on skin and its use in forensic identification procedures. Braz Oral Res 2005;19(3):216-22.

TABLE 1 - DNA typing results of 15 STRs for saliva samples from donors (1-13) (Continued on page 219).

\begin{tabular}{|c|c|c|c|c|c|c|c|c|c|c|c|c|c|}
\hline STR & 1 & 2 & 3 & 4 & 5 & 6 & 7 & 8 & 9 & 10 & 11 & 12 & 13 \\
\hline \multirow{2}{*}{ D3S1358 } & 16 & 15 & - & 16 & 15 & 17 & - & 18 & - & 16 & 15 & 14 & 16 \\
\hline & 17 & 17 & - & 18 & 16 & 18 & - & 18 & - & 18 & 15 & 16 & 18 \\
\hline \multirow{2}{*}{ D5S818 } & 8 & 9 & - & 10 & 10 & 11 & 9 & 10 & 9 & 10 & 11 & 9 & 9 \\
\hline & 9 & 10 & - & 11 & 11 & 12 & 10 & 10 & 11 & 11 & 11 & 10 & 9 \\
\hline \multirow{2}{*}{ D7S820 } & 10 & 10 & 10 & 10 & 10 & 10 & - & 9 & 10 & 8 & 10 & 11 & 10 \\
\hline & 11 & 11 & 13 & 11 & 12 & 11 & - & 12 & 11 & 10 & 11 & 11 & 12 \\
\hline \multirow{2}{*}{ D13S317 } & 9 & 13 & 10 & 10 & 13 & 14 & 15 & 14 & 14 & 11 & 12 & 10 & 12 \\
\hline & 10 & 13 & 10 & 11 & 15 & 14 & 15 & 15 & 14 & 13 & 12 & 12 & 14 \\
\hline \multirow{2}{*}{ D16S539 } & 8 & 11 & 10 & 9 & 11 & 11 & - & 11 & 5 & 11 & 9 & 9 & 11 \\
\hline & 12 & 13 & 11 & 12 & 12 & 13 & - & 13 & 11 & 11 & 13 & 11 & 12 \\
\hline \multirow{2}{*}{ D18S51 } & 10,2 & 16 & 9 & 10,2 & 9 & 13 & 10 & 10 & 18 & 9 & 12 & - & 12 \\
\hline & 15 & 23 & 9 & 15 & 14 & 23 & 24 & 23 & 22 & 11 & 12 & - & 12 \\
\hline \multirow{2}{*}{ D19S253 } & 21 & 21 & 23 & 23 & 21 & 17 & 9 & 23 & 9 & 9 & 9 & 9 & 9 \\
\hline & 21 & 21 & 23 & 23 & 21 & 19 & 21 & 23 & 21 & 19 & 23 & 9 & 17 \\
\hline \multirow{2}{*}{ D21S11 } & 31 & 31 & 29 & 29 & 30 & 29 & 28 & 28 & 30 & 28 & 29 & 28 & 28 \\
\hline & 33,2 & 31 & 31 & 30 & 30 & 30 & 31 & 32,2 & 30 & 30 & 30 & 31 & 28 \\
\hline \multirow{2}{*}{ F13A01 } & 7 & 5 & 4 & 4 & 3 & 7 & 6 & 4 & - & 5 & - & - & - \\
\hline & 7 & 7 & 4 & 4 & 7 & 7 & 6 & 4 & - & 5 & - & - & - \\
\hline \multirow{2}{*}{ F13B } & 10 & 8 & 9 & 9 & 8 & 9 & 9 & 6 & 9 & 8 & 8 & 6 & 8 \\
\hline & 10 & 9 & 9 & 10 & 10 & 9 & 9 & 10 & 9 & 9 & 10 & 9 & 10 \\
\hline \multirow{2}{*}{ FES/ FPS } & 11 & 11 & 12 & 12 & 11 & 10 & 12 & 11 & - & 11 & 11 & 10 & 12 \\
\hline & 13 & 12 & 13 & 12 & 11 & 10 & 13 & 12 & - & 11 & 11 & 13 & 12 \\
\hline \multirow{2}{*}{ FGA } & 23 & 20 & 20 & 18 & 20 & 20 & 19 & 20 & 22 & 19 & 20 & 23 & 22 \\
\hline & 24 & 24 & 22 & 22 & 24 & 21 & 19 & 24 & 23 & 24 & 22 & 26 & 23 \\
\hline \multirow{2}{*}{$\mathrm{SE}-33$} & A14 & A12 & - & $\mathrm{A} 12$ & A19 & A15 & A14 & A19 & A19 & A17 & A16 & A13 & A2 1 \\
\hline & A7 & A5 & - & A9 & A8 & A12 & A8 & A18 & A12 & A8 & A4 & A4 & A9 \\
\hline \multirow{2}{*}{ TH01 } & 6 & - & 6 & 8 & 8 & 6 & 6 & 7 & 8 & 9 & 8 & 6 & 6 \\
\hline & 6 & - & 7 & 9,3 & 9 & 8 & 9 & 9 & 9 & 9 & 9 & 8 & 7 \\
\hline \multirow{2}{*}{ vWA } & 16 & 15 & 13 & 17 & 15 & 13 & 16 & 16 & 16 & 15 & 15 & 15 & 13 \\
\hline & 16 & 15 & 18 & 17 & 16 & 15 & 16 & 16 & 17 & 16 & 18 & 18 & 16 \\
\hline $\begin{array}{c}\text { Quant/DNA } \\
(\mu \mathrm{g})\end{array}$ & 25.7 & 27.8 & 31.4 & 67.9 & 40.3 & 156 & 12.8 & 39.6 & 16.0 & 16.1 & 90.8 & 93.5 & 151 \\
\hline
\end{tabular}

(-) allele not found. Quant: quantification.

samples were digested with $700 \mu 1$ of lysis buffer (Sigma-Aldrich Co., St. Louis, MO, USA) (10 mM Tris, $\mathrm{pH} 8.0 ; 10 \mathrm{mM}$ EDTA, $\mathrm{pH} 8.0 ; 0.1 \mathrm{M} \mathrm{NaCl}$; $2 \%$ SDS) containing $35 \mu 1$ of Proteinase K (Invitrogen, Carlsbad, CA, USA) $(20 \mathrm{mg} / \mathrm{mL})$. DNA extraction was carried out by the phenol-chloroform method $^{10}$ (Phenol: Invitrogen, Carlsbad, CA, USA; Chloroform: Merck, Darmstadt, Germany).
After precipitation with ethanol (Merck, Darmstadt, Germany); DNA from saliva samples and skin swabs were resuspended in $100 \mu 1$ and $30 \mu 1$ of TE (Sigma-Aldrich Co., St. Louis, MO, USA) (10 mM Tris-HCl, pH 8.0; 1 mM EDTA, pH 8.0), respectively. DNA was quantified using the Beckman DU ${ }^{\circledR} 640$ (Beckman Coulter, Inc., Fullerton, 
Anzai-Kanto E, Hirata MH, Hirata RDC, Nunes FD, Melani RFH, Oliveira RN. DNA extraction from human saliva deposited on skin and its use in forensic identification procedures. Braz Oral Res 2005;19(3):216-22.

TABLE 1 - (continued) DNA typing results of 15 STRs for saliva samples from donors (14-20) and researcher (cont.), and saliva deposited on skin (A-E).

\begin{tabular}{|c|c|c|c|c|c|c|c|c|c|c|c|c|c|}
\hline $\begin{array}{l}\text { Samples } \\
\text { STR }\end{array}$ & 14 & 15 & 16 & 17 & 18 & 19 & 20 & A & B & $\mathrm{C}$ & $\mathrm{D}$ & $\mathrm{E}$ & Cont. \\
\hline \multirow{2}{*}{ D3S1358 } & 15 & 16 & 16 & 17 & 17 & 16 & 15 & - & 17 & - & - & - & 15 \\
\hline & 16 & 17 & 18 & 17 & 18 & 17 & 15 & - & 18 & - & - & - & 16 \\
\hline \multirow{2}{*}{ D5S818 } & 8 & 9 & 7 & 8 & 7 & 8 & 8 & - & - & - & - & - & 9 \\
\hline & 10 & 10 & 8 & 10 & 8 & 9 & 10 & - & - & - & - & - & 10 \\
\hline \multirow{2}{*}{ D7S820 } & 9 & 6 & 11 & 10 & 10 & 11 & 11 & - & - & - & - & - & 10 \\
\hline & 10 & 9 & 12 & 12 & 10 & 12 & 12 & - & - & - & - & - & 12 \\
\hline \multirow{2}{*}{ D13S317 } & 12 & 10 & 15 & 10 & 14 & 11 & 11 & - & - & - & - & - & 13 \\
\hline & 15 & 14 & 15 & 14 & 14 & 13 & 13 & - & - & - & - & - & 15 \\
\hline \multirow{2}{*}{ D16S539 } & 9 & 9 & 11 & 10 & 12 & 10 & 11 & - & 11 & - & - & - & 11 \\
\hline & 12 & 10 & 13 & 13 & 12 & 11 & 11 & - & 13 & - & - & - & 11 \\
\hline \multirow{2}{*}{ D18S51 } & 9 & 12 & 11 & 14 & 9 & 10,2 & 11 & - & - & - & - & - & 10 \\
\hline & 9 & 12 & 11 & 14 & 11 & 14 & 11 & - & - & - & - & - & 17 \\
\hline \multirow{2}{*}{ D19S253 } & 21 & 9 & 21 & 11 & 13 & 9 & 21 & - & 17 & 9 & - & - & 21 \\
\hline & 21 & 23 & 21 & 25 & 19 & 23 & 23 & - & 19 & 21 & - & - & 21 \\
\hline \multirow{2}{*}{$\mathrm{D} 21 \mathrm{~S} 11$} & 30 & 28 & 29 & 28 & 29 & 28 & 28 & - & - & - & - & - & 27 \\
\hline & 30 & 30 & 30 & 28 & 29 & 32 & 32 & - & - & - & - & - & 30 \\
\hline \multirow{2}{*}{ F13A01 } & 6 & 8 & 4 & 6 & 6 & 7 & 7 & - & - & - & - & - & 6 \\
\hline & 6 & 8 & 4 & 6 & 6 & 7 & 7 & - & - & - & - & - & 6 \\
\hline \multirow{2}{*}{ F13B } & 9 & 9 & 9 & 8 & 9 & 8 & 8 & - & - & - & - & - & 9 \\
\hline & 9 & 9 & 9 & 10 & 9 & 8 & 10 & - & - & - & - & - & 9 \\
\hline \multirow{2}{*}{ FES/ FPS } & 11 & 11 & - & 11 & 10 & 11 & 10 & - & 10 & - & - & - & 10 \\
\hline & 11 & 13 & - & 11 & 11 & 11 & 12 & - & 10 & - & - & - & 13 \\
\hline \multirow{2}{*}{ FGA } & 19 & 19 & 20 & 19 & 19 & 21 & 22 & - & - & - & - & - & 22 \\
\hline & 25 & 27 & 22 & 19 & 19 & 22 & 25 & - & - & - & - & - & 25 \\
\hline \multirow{2}{*}{$\mathrm{SE}-33$} & A9 & A12 & A17 & A16 & - & A18 & A8 & A19 & A15 & A14 & - & - & A15 \\
\hline & A9 & A12 & A8 & A5 & - & A17 & A8 & A8 & A12 & A8 & - & - & A10 \\
\hline \multirow{2}{*}{ TH01 } & 9 & 9 & 8 & 6 & 6 & 8 & 6 & - & 6 & 6 & - & 6 & 5 \\
\hline & 9 & 9 & 8 & 8 & 6 & 9 & 7 & - & 8 & 9 & - & 7 & 6 \\
\hline \multirow{2}{*}{ vWA } & 14 & - & 14 & 15 & 14 & 13 & 13 & - & - & - & - & - & 13 \\
\hline & 16 & - & 15 & 15 & 16 & 16 & 15 & - & - & - & - & - & 13 \\
\hline $\begin{array}{c}\text { Quant/DNA } \\
(\mu \mathrm{g})\end{array}$ & 91.7 & 83.9 & 26.7 & 25.9 & 56.2 & 95.2 & 29.9 & 3.0 & 4.8 & 3.4 & 5.4 & 4.2 & 63.3 \\
\hline
\end{tabular}

(-) allele not found. Quant: quantification.

USA) spectrophotometer and purity was verified at a $260 / 280 \mathrm{~nm}$ ratio.

\section{DNA typing}

Fifteen STRs of human genomic DNA were amplified by PCR. Sets of primers for D3S1358 ${ }^{12}$,
D5S818, D7S820, D13S317 ${ }^{10}, \mathrm{D} 16 \mathrm{~S} 539^{13}$, D18S51, D19S253, FGA ${ }^{28}, \mathrm{D} 21 \mathrm{~S} 11, \mathrm{~F} 13 \mathrm{~A} 01$, THO $1^{27}, \mathrm{~F}_{13 B^{16}}, \mathrm{FES} / \mathrm{FPS}^{19}, \mathrm{SE}-33$ or ACTBP $2^{18}$ and VWA ${ }^{15}$ were labeled with Cy5 (Cy5-bis-OSU, N,N'-biscarboxypentyl-5,5'-disulfonatoindodicarbocyanine) at the 5'-end (Synthegen, Houston, TX, USA). PCR were previously standardized for the 15 
Anzai-Kanto E, Hirata MH, Hirata RDC, Nunes FD, Melani RFH, Oliveira RN. DNA extraction from human saliva deposited on skin and its use in forensic identification procedures. Braz Oral Res 2005;19(3):216-22.

STRs using $25 \mathrm{mM} \mathrm{MgCI}$ (GE Healthcare, Chalfont, St. Giles, United Kingdom), $10 \mathrm{mM}$ of each dNTP (GE Healthcare, Chalfont, St. Giles, United Kingdom), $80 \mathrm{nM}$ of each primer, $1 \mathrm{U}$ Taq DNA polymerase (GE Healthcare, Chalfont, St. Giles, United Kingdom) and 200 ng to 500 ng of genomic DNA to a final volume of $25 \mu$ l. DNA fragments were amplified in the model PTC-100 thermocycler (MJ Research, Watertown, MT, USA) with the following program: pre-denaturation at $98^{\circ} \mathrm{C}$ for $5 \mathrm{~min}, 35$ cycles of $94^{\circ} \mathrm{C}$ for $1 \mathrm{~min}, 56^{\circ} \mathrm{C}$ for $1 \mathrm{~min}$, and $72^{\circ} \mathrm{C}$ for $2 \mathrm{~min}$; and final extension of $72^{\circ} \mathrm{C}$ for $10 \mathrm{~min}$. These PCR conditions were used for all 15 STRs.

PCR products were diluted with $40 \%$ of a loading dye buffer (GE Healthcare, Chalfont, St. Giles, United Kingdom) (100\% formamide and 0.05\% Dextran blue 2000) and $1.0 \mu 1$ was loaded in a $20 \%$ polyacrylamide gel (GE Healthcare, Chalfont, St. Giles, United Kingdom) in denaturing conditions (acrylamide/bis:19/1) in TBE buffer (SigmaAldrich Co., St. Louis, MO, USA) (Tris base $9 \mathrm{mM}$, boric acid $9 \mathrm{mM}$, EDTA $1 \mathrm{mM} \mathrm{pH} \mathrm{8.0)} \mathrm{and} \mathrm{electro-}$ phoresed at 1,500 volts, $60 \mathrm{~mA}$, at $55^{\circ} \mathrm{C}$, for $2 \mathrm{~h}$ using the ALF Express System (GE Healthcare, Chalfont, St. Giles, United Kingdom). The electrophoresis separation and analysis of fragments with peak patterns were analyzed using ALF win Instrument Control Version 2.00 and Allele Locator Software (GE Healthcare, Chalfont, St. Giles, United Kingdom). The ladder ALF Express Sizer ${ }^{\mathrm{TM}}$ 50-500 (GE Healthcare, Chalfont, St. Giles, United Kingdom) and allelic ladder were used as standard to determine the allelic size of the STRs.

The allelic frequency of the Brazilian population $^{2,7,17}$ was used as reference and the match among samples was calculated on the basis of Likelihood Ratio (LR) ${ }^{6}$.

\section{RESULTS}

The DNA quantification of 20 saliva samples resulted in an average of $58.9 \pm 43.2 \mu \mathrm{g}$. The amount of DNA of the 5 samples, named "A", "B", "C", "D" and "E", deposited on skin $(250 \mu 1)$ resulted in an average of $4.2 \pm 0.9 \mu \mathrm{g}$. DNA recovery from skindeposited saliva was 14 to 10 times lower than DNA from saliva samples $(\mathrm{p}<0.05)$. The DNA extracted from saliva samples collected from skin presented a $\mathrm{A}^{260} / \mathrm{A}^{280}$ ratio of $\mathrm{A}=1.4476 ; \mathrm{B}=1.8466$; $\mathrm{C}=2.0751 ; \mathrm{D}=2.2118$ and $\mathrm{E}=1.5737$. The DNA typing of all saliva and control samples and skin swabs is shown in Table 1. STRs were amplified in 4 of 5 DNA samples extracted from saliva deposited on skin.
Despite the small number of amplified loci in the saliva samples collected from skin, it was possible to match the alleles of these loci in the 20 saliva samples, A with 5 , B with $6, \mathrm{C}$ with $7, \mathrm{E}$ with 3 or 13 or 20 . The likelihood ratios based on data from the Brazilian population were A 1:500; B 1:153.700.123; C 1:159.140; and E 1:11.

\section{DISCUSSION}

All the DNA profiles were obtained from the 20 samples, which could be compared with the other five samples deposited on skin. STRs were amplified in 4 out of the 5 DNA samples extracted from saliva deposited on skin, and that is probably related to the lower recovery of DNA from skindeposited saliva.

The single loci amplification was used in this research; however, the multiple loci amplification could also have been used. The Spanish and Portuguese Working Group of the International Society for Forensic Genetics (SPWG-ISFG), who develop guidelines for and discuss quality assurance and control program in forensic genetics, accepts manual or semiautomatic STR typing and single or multiple loci amplification ${ }^{1}$. In a multiplex system, it is likely that more loci would be amplified ${ }^{22}$, but this was not tested.

To control contamination between DNA samples, we prepared them in separate rooms, with UV germicidal lamps that damage any DNA left on exposed surfaces. The solutions were autoclaved, reagents were divided into aliquots and mixed prior to being divided into aliquots; DNA was added in another room and positive and negative controls were used. This procedure was very important to avoid false positives with $\mathrm{PCR}^{11}$.

Another relevant aspect occurs when the amount of evidence available is minimal ${ }^{22}$, because the DNA sample may not be enough to accomplish the DNA typing. However, in the present study, the DNA quantity from saliva deposited samples was sufficient for PCR amplification and typing. Nevertheless, in sample D no alleles were amplified. The $A^{260} / A^{280}$ ratio of DNA extracted from saliva samples colleted from skin cannot justify sample $\mathrm{D}$ negative loci amplification. Perhaps, unknown PCR enzyme inhibitors could be present in saliva samples ${ }^{26}$, or salivary DNA was not extracted in enough amount to allow amplification. We have to consider that saliva may have microorganisms ${ }^{4}$ that can be source of DNA that can be extracted and quantified. It was demonstrated that DNA recovery from the saliva deposited on skin was 
Anzai-Kanto E, Hirata MH, Hirata RDC, Nunes FD, Melani RFH, Oliveira RN. DNA extraction from human saliva deposited on skin and its use in forensic identification procedures. Braz Oral Res 2005;19(3):216-22.

not proportionally equivalent to the DNA quantity found in the 20 saliva samples. Saliva deposition, salivary cell collection and DNA extraction procedures probably reduce the DNA quantity.

Despite the small number of amplified loci in the saliva samples collected from the skin, it was possible to match the alleles of these loci in the 20 saliva samples (A with 5 , B with 6 , C with 7 , E with 3 or 13 or 20). The likelihood ratios based on data from the Brazilian population that varied from 1:11 to $1: 159.140$ suggest that STR analysis in DNA samples from skin-deposited saliva can be used as strong evidence to assist the criminal process ${ }^{22,26}$ by exclusion or inclusion of suspects. However, the solution of a forensic case requires other important studies such as the physical bite mark and other evidences found in the crime scene that should be well addressed by the investigators.

In this experimental study, it is important to consider that there is no contact between lips and teeth and skin, as happens in a real case, where buccal cells are impregnated on skin, which can

\section{REFERENCES}

1. Alonso A, Albarran C. The Spanish and Portuguese ISFG Working Group: ten years coordinating DNA typing in Spain, Portugal and Latin America. Profiles DNA 2000;4(1):7-8.

2. Barros de Castro IA, Rinzler CMC, Rumjanek FD. Allele frequency distributions for twelve STR loci in a Brazilian population. J Forensic Sci 2000;45(4):941.

3. Bernitz H, van Niekerk PJ. Bungled bite mark evidence collection: a proposed protocol for the prevention thereof. SADJ 2003;58:16-9.

4. Borgula LM, Robinson FG, Rahimi M, Chew KE, Birchmeier $\mathrm{KR}$, Owens $\mathrm{SG}$, et al. Isolation and genotypic comparison of oral streptococci from experimental bitemarks. J Forensic Odontostomatol 2003;21(2):23-30.

5. Clark DH. Practical forensic odontology. Oxford: Wright; 1992.

6. Evett IW, Weir BS. Interpreting DNA evidence. Suderland: Sinauer Associates; 1998.

7. Grattapaglia D, Schmidt AB, Costa e Silva C, Stringher C, Fernandes AP, Ferreira ME. Brazilian population database for the 13 STR loci of the AmpFlSTR ${ }^{\circledR}$ Profiler Plus $^{\mathrm{TM}}$ and Cofiler ${ }^{\mathrm{TM}}$ multiplex kits. Forensic Sci Int 2001;118:91-4.

8. Harvey W. Dental identification and forensic odontology. London: Kimpton; 1976.

9. Hochmeister MN, Rudin O, Ambach E. PCR analysis from cigarette butts, postage stamps, envelope sealing flaps, and other saliva-stained material. In: Lincoln PJ, Thomson J, editors. Forensic DNA profiling protocols. Totowa: Humana Press; 1998. p. 27-32. Methods in molecular biology, 98.

10. Jin L, Underhill PA, Buoncristiani MR, Robertson JM. Defining microsatellite alleles by genotyping global indigenous human populations and non-human primates. J Forensic Sci 1997;42:496-9. increase cell quantity. In a real case, there is tissue invasion, with the possibility of mixing the victim's and the aggressor's DNA ${ }^{27}$. When there are mixtures, the contamination can be recognized during case investigation, comparing the victim's DNA and the DNA of the suspect. However, in this research, the results showed that DNA samples from skin-deposited saliva were not mixed with control DNA, corroborating the results from another similar previous study ${ }^{26}$.

\section{CONCLUSION}

Our results indicate that standardized procedures for DNA collection and extraction from skin-deposited saliva can be very useful to help solving criminal cases, since important data may be obtained using salivary DNA analysis. Therefore, the analysis of saliva deposited on skin can be incorporated into a criminal investigation and have great discriminatory power.

11. Kwok S, Higuchi R. Avoiding false positives with PCR. Nature 1989;339:237-8.

12. Li H, Schmidt L, Wei MH, Hustad T, Lerman MI, Zbar B, et al. Three tetranucleotide polymorphisms for loci: D3S1352, D3S1358, D3S1359. Hum Mol Genet 1993;2:1327.

13. Lins AM, Micka KA, Sprecher CJ, Taylor JA, Bacher JW, Rabbach D, et al. Development and population study of an eight-locus short tandem repeat (STR) multiplex system. J Forensic Sci 1998;43(6):1168-80.

14. Mesquita RA, Anzai EK, Oliveira RN, Nunes FD. Evaluation of 3 methods of DNA extraction from paraffin-embedded material for the amplification of genomic DNA using PCR. Pesqui Odontol Bras 2001;15(4):314-9.

15. Moller A, Wiegand P, Gruschow C, Seuchter SA, Baur MP, Brinkmann B. Population data and forensic efficiency values for the STR systems HumVWA, HumMBP and HumFABP. Int J Legal Med 1994;106:183-9.

16. Nishimura DY, Murray JC. A tetranucleotide repeat for the F13B locus. Nucleic Acids Res 1992;20:1167.

17. Ozaki NA. Determinação da freqüência de genes de algumas regiões hipervariáveis do genoma humano para estudo do vínculo genético familiar em caucasianos brasileiros [Dissertação de Mestrado]. São Paulo: Faculdade de Ciências Farmacêuticas da USP; 1999.

18. Polymeropoulos MH, Rath DS, Xiao H, Merril CR. Tetranucleotide repeat polymorphism at the human beta-actin related pseudogene H-beta-Ac-psi-2 (ACTBP2). Nucleic Acids Res 1992;20:1432.

19. Polymeropoulos MH, Rath DS, Xiao H, Merril CR. Tetranucleotide repeat polymorphism at the human c-fes/fps proto-oncogene (FES). Nucleic Acids Res 1991;19:4018. 
Anzai-Kanto E, Hirata MH, Hirata RDC, Nunes FD, Melani RFH, Oliveira RN. DNA extraction from human saliva deposited on skin and its use in forensic identification procedures. Braz Oral Res 2005;19(3):216-22.

20. Saiki RK, Scharf SJ, Faloona F, Mullis KB, Horn GT, Erlich HA, et al. Enzymatic amplification of beta-globin sequences and restriction site analysis for diagnosis of sickle cell anemia. Science 1985;230(4732):1350-4.

21. Soares-Vieira JA, Munoz DR, Iwamura ES, de Almeida Cardoso L, Billerbeck AE. Analysis of DNA in minute volumes of blood from stains and crusts. Am J Forensic Med Pathol 2001;22(3):308-12.

22. Sweet D, Hildebrand D. Saliva from cheese bite yields DNA profile of burglar: a case report. Int J Legal Med 1999;112:201-3.

23. Sweet D, Lorente M, Lorente JA, Valenzuela A, Villanueva E. An improved method to recover saliva from human skin: the double swab technique. J Forensic Sci 1997;42:320-2.

24. Sweet D, Lorente M, Valenzuela A, Lorente JA, Alvarez JC. Increasing DNA extraction yield from saliva stains with a modified Chelex method. Forensic Sci Int 1996;83:167-77.
25. Sweet D, Pretty IA. A look at forensic dentistry - Part 2: teeth as weapons of violence - identification of bitemark perpetrators. Br Dent J 2001;190:415-8.

26. Sweet D, Shutler GG. Analysis of salivary DNA evidence from a bite mark on a body submerged in water. J Forensic Sci 1999;44:1069-72.

27. Urquhart A, Kimpton CP, Downes TJ, Gill P. Variation in short tandem repeat sequences - a survey of twelve microsatellite loci for use as forensic identification markers. Int J Legal Med 1994;107:13-20.

28. Urquhart A, Oldroyd NJ, Kimpton CP, Gill P. Highly discriminating heptaplex short tandem repeat PCR system for forensic identification. Biotechniques 1995;18:116-21.

29. Wright FD, Dailey JC. Human bite marks in forensic dentistry. Dent Clin North Am 2001;45:365-97.

Received for publication on Aug 03, 2004

Sent for alterations on Jun 13, 2005

Accepted for publication on Jul 21, 2005 